\title{
REMEDIATION OF OIL-CONTAMINATED SOILS
}

\author{
Ludmila P. Kapelkina \\ Marina V. Chugunova \\ Ludmila G. Bakina \\ St.-Petersburg Scientific Research Center for Ecological Safety
}

\begin{abstract}
The great quantities of the produced and transported oil cause high risk of accidental spill. The accidental oil spills are classified according to the significance and location of the site (green area of the city, protection zone, thinly populated land, etc.), volume of the spilled oil, size of the oil-contaminated site, availability for remediation (transport communications), and the type of oil-contaminated soil.
\end{abstract}

The choice of the remediation method depends on this classification and on time, passed from the moment of the accident. The cleanup of oil spill can be divided into three principal stages: the localization of the contaminated site, the collection and utilization of the spilled oil and recultivation of the contaminated soil. The liquidation works must be done after localization of the spill, namely, it is the collection and pumping of the oil with mechanical devices and subsequent oil return in the technological process.

It is known that mechanical and physico-chemical sanitation methods can not completely purify the oil-contaminated soils. The total purification is possible only as a result of oil biodegradation (biochemical oxidation). There are two main approaches to oil biodegradation: 1) stimulation of aboriginal microflora activity by formation of optimum conditions for it development; 2) introduction of the active hydrocarbons-oxidizing microbes (biopreparations) into contaminated soil.

During the field experiments the various maneuvers of oil-contaminated soil recultivation have been tested: loosening; fertilizing and liming; cleaning with biopreparations; sowing of plants stable to oil.

\section{KEYWORDS}

Remediation; Recultivation; Technological schemes; Oil-contaminated soil; Oil spills; Booms; Sorbents; Oil collecting facilities; Vegetation, peat; Hydrocarbons oxidizing microflora. 


\section{INTRODUCTION}

Considerable reserves of currently developed oil fields are located in West Siberia and in the North of European part of Russia. Accidental oil spills are mostly caused (over $90 \%$ ) by corroded pipelines, therefore major preventive measure against oil spills is pipeline corrosion control. The accidental oil spills are classified according to the significance and location of the site (green area of the city, protection zone, thinly populated land, etc.), volume of the spilled oil, size of the oil-contaminated site, availability for remediation (transport communications), and the type of oil-contaminated soil. The choice of the remediation method depends on this classification and on time, passed from the moment of the accident.

The cleanup of an oil spill can be divided into three principal stages: localization of the contaminated site, collection and utilization of the spilled oil and recultivation of the contaminated soil. After an oil spill is isolated it is necessary to conduct eliminating operations, the greatest possible amount of oil should be collected and pumped off mechanically, with its further utilization and recycling. Oil collecting facilities should be mobile, correspond to climatic and landscape conditions, parameters of the oil being removed, and requirements to operational safety. Along with collection and pumping off of oil it is expedient to flush oil-contaminated sites with water (the site being banked or trenched), to flood the sites with water and collect the oil products from the water surface, to cut off the oilcontaminated frozen soil with a bulldozer and remove it to special ranges, to remove oil with scrapers and other implements.

The first thing to do in rehabilitation of oil-contaminated territories is to evaluate the territory and the environmental situation in a spillage area. Together with classification features of the spill, the ecological condition of the site is taken into account: occurrence of dead vegetation (trees), the depth of oil penetration, oil's viscosity and mobility, occurrence of a crust on top, and also the relief of the contaminated area, the passing ability for people and vehicles. The effectiveness of eliminating activities of spilled oil collecting directly affects the productivity of further recultivation.

In the early 1990's OJSC Surgutneftegaz was researching the efficiency of oil skimmer preproduction prototypes manufactured in Tyumen, Nizhnevartovsk, and Samara. They all had, though, certain drawbacks: insufficient floatability, low operational features. Therefore, from 1994 on, foreign oil collecting facilities have been studied. The preference was given to the machines produced by Vikoma (Great Britain) with a view to using them under West Siberian conditions.

Currently OJSC Surgutneftegaz has 89 units of oil skimmer with capacities from 1 to $132 \mathrm{t} / \mathrm{h}$ for collecting oil of various viscosities (Sea Devil, Mini Fasflo, Komara 12MK11, Delta, Powervak) with different collection principles including vacuum, excavator, and adhesion ones. Portable quick-deployable slick bars are used to isolate oil. Portable self-erecting capacities Vicotank are used to store oil temporarily as well as boom, roll and lamella sorbents. The latest developments of this company appeared to be highly effective. They are: bacterial sprinklers of various capacities, self-driven transfer pumps, and quick-screwed aluminum pipes for places removed from roads, oil skimmer "Komara Star" for operation at temperatures up to $-20^{\circ} \mathrm{C}$, “Komara 30 ", "Seaskimmer-50".

The use of sorbents, both as booms and when atomizing them, appeared to be efficient at elimination of accidental oil spills on water bodies. Sorbent production equipment (through 
thermal decomposition of oxidized graphite), sorbent boom forming and squeezing machines have been put into operation to produce sorbents. The productive capacity of a boom former can reach $100 \mathrm{~m} / \mathrm{h}$. Such equipment and materials allow producing booms, using them up to 10 times with squeezing, and utilizing the squeezed oil. Also three Vycoma oil-spill boats are used. When loaded, these boats have a draft of $60 \mathrm{~cm}$; therefore they fit for work in shallow waters. The boat is equipped with two detachable devices to collect oil of various viscosities: with sprocket disks (of Sea Devil type) to collect viscous oil and operating at temperatures below zero, and also with polymer disks to collect light oil with two on-board reservoirs $2 \mathrm{~m}^{2}$ each and a pump to transfer oil onshore.

After the greatest possible amount of oil is collected the recultivation starts. When selecting specific techniques for reclaiming oil-contaminated soils, the location of oil-contaminated sites in relation to populated areas, roads, lands, conservation territories, etc. should be considered. The full set of activities during the recultivation of contaminated land should take place on the most important sites. It is admissible to leave the remote areas for the oil natural biodegradation, if only the oil has been isolated and pumped off and there is no risk of its getting into water conduits. In this case we assume that it is impossible to conduct the full set of recultivation activities on the entire area of the oil-contaminated land, for the areas and sizes of contamination are incommensurable to the real possibility of its complete elimination. Technological solutions should be well-grounded and meet criteria of environmental safety and economic efficiency.

The ultimate goal of recultivation activities is to bring oil-contaminated sites back to approve standards, and to optimize water, air, and food conditions of soils for vegetation of cultivated or wild flora.

Recultivation flow charts vary depending on conditions, location of the oil-contaminated site, the spillage period, etc. The most rigid requirements to the cleaning of territories and to the quality of recultivation activities should be on areas within cities' and settlements' green belts, in water protection zones, on conservation areas, along federal roadways. Technological operations may include supplying peat and covering of an oil-contaminated area with it, soil loosening, application of lime (the dose is determined by peat acidity), mineral fertilizers, sowing of perennial grass, treating the area with biological preparations, etc.

In order to stimulate natural vegetation of local or adapted grasses, it is advisable to use local sowing with lowered sowing rates $(5-10 \%$ of the principal one) on remote areas. Such areas can be transferred to land users when there are signs of natural vegetation or plants appear after artificial sowing.

Realization of experiment and manufacturing operations during the cleaning of oil contaminated swampy grounds require observation of special safety measures. Some sections of swamps become practically pathless; the risk of falls grows due to partial loss of roots, lowered bonding of root systems, and enhanced slipping of roots in relation to each other. On peat bogs the passage is inhibited due to enhanced oil viscosity. Manual operations during the recultivation should be brought to a minimum in most cases.

\section{RECULTIVATION TECHNIQUES OF OIL-CONTAMINATED SOILS}

The following section describes the details of the major recultivation techniques of oilcontaminated soils. 


\subsection{Mechanical treatment of soil}

Mechanical treatment of soil is conducted with forestry or agricultural machinery. The area is processed with milling or disk harrows. Mechanical mixing of an oil-contaminated layer with the underlying clean one reduces oil content in the surface layer, strengthens aeration of soils. As a result, biochemical destruction of hydrocarbons is intensified, the redox potential grows, and conditions for microbiological activities improve. This operation should be conducted after most toxic light oil fractions evaporate. Destruction of the crust on old spills speeds up oil degradation. Special machines can be used to loosen the soil, such as Finnish marsh buggies, rippers designed by NPO Priborservis (Tomsk).

\subsection{Biological recultivation}

This technique involves the application of peat, which is the most efficient natural sorbent, onto the cleaned surface and subsequent mixing. This reduces oil content in the surface soil layer and creates conditions for plant growth. On an area with the highly contaminated surface where oil has not been collected and pumped off, peat application is inadvisable.

During spring tide and heavy rain in summer oil can rise up to the surface with groundwater. In this case, sometimes it can be sufficient just to collect and pump off the oil and then leave the area for natural purification.

Supply and covering of an oil-contaminated area with peat together with subsequent loosening should be performed only when such operations will bring oil concentration in the surface layer of the soil (for instance of swamp soil) to no more than 10-12\%, and the possibility of plants to appear and grow is assured. At the same time, during reclaiming activities on podzolic soils with very low reserves of organic matter, good results can be obtained when organic fertilizers are applied, particularly peat.

\subsection{Application of mineral fertilizers and lime}

Agrochemical methods include application of biogenic elements (preferably nitrogen and phosphorus) and reduction of excess acidity to stimulate natural purification of soils. At that, favorable conditions are created for destruction of hydrocarbons which are very difficult to decompose, such as polyaromatic hydrocarbons and naphthenes. Besides, number of microorganisms which are oil destructors grows by $1-2$ orders.

Lack of nutrients, of nitrogen in the first place, can cause competition between microorganisms and plants in the soil. In oil-contaminated soil carbon/nitrogen ratio (C:N) can reach 40 and above, whereas it should be about 10 to allow bacteria to grow. Application of nitrogen fertilizers optimizes this parameter. Liming is an efficient technique of oilcontaminated soil reclamation, which optimizes living conditions of hydrocarbon oxidizing microflora. Lime doses are determined by soil types and $\mathrm{pH}$ value. Most peat bog soils around Surgut are characterized by $\mathrm{pH}_{\mathrm{kcl}} 3.5-4.5$, i.e. the soils are strongly acidic. Therefore, lime doses used here as a chemical ameliorant can vary within $4-8 \mathrm{t} / \mathrm{ha}$.

\subsection{Microbiological treatment of contaminated soils}

Microbiological treatment of contaminated soils intensifies oil decomposition. Under favorable environmental conditions (presence of nutrients, optimal $\mathrm{pH}$ values, sufficiently high air temperature, good aeration, etc.) tangible results in soil purification can be attained. Application of strains of active hydrocarbon decomposing microorganism makes sense only 
in case of singling out aboriginal species adapted to the conditions of a given territory. On excessively moisturized peat bog soils the treatment should proceed with more concentrated process solutions, which allows reducing considerably the amounts of the applied liquid. Fertilizers are required for adequate nutrition of microbe cells comprised in the preparations, and also for activation of aboriginal oil oxidizing flora.

\subsection{Sowing and planting on oil-contaminated soils}

This technique speeds up the decomposition of hydrocarbons due to improved aeration. Aeration is improved due to development of root systems. Besides, root systems of plants exude biologically active substances stimulating the growth of microorganisms, that in turn intensifies the degradation of oily hydrocarbons.

Seed farming of plants resistant to soil contamination with oil has not been established so far. Recultivated sites are sown with herbaceous plants designed for city lawn coverings or agricultural mowing farms and pastures. These species require high agricultural engineering and regulated cares; therefore, they are not lasting on recultivated soils. It is necessary to use local plant species resistant to extreme conditions. For example, though sowing of nonadapted to swampy landscapes grass ensures coverage of the surface for the initial periods, it is not stable and later on substituted with aboriginal species. Currently, seeds of cotton grass, sedges, cassandra, moss spores, etc. are not sold.

It is advisable to sow grass indicatively with the sowing rates of $5-10 \%$. The appearance of sprouts and normal development of the plants will give evidence that plants are capable of growing on the given site. In other words, the quality of soils in relation to the degree of oil contamination can be determined by the state of natural vegetation and sown grass. Later on, the oil on the site will undergo biological degradation and conditions for plant growth will be improving.

Table 1 shows the recultivative technological schemes speeding up the decomposition of oil and restoration of soils and vegetation. Activities in oil-contaminated land recultivation in the industrial conditions on specific soils, and growing experience will make it possible to upgrade such techniques, choosing the most efficient ones.

Eliminative and recultivative operations of oil-contaminated soils have social and conservation significance and are directed towards reduction of negative impact of oil contamination on the natural ecosystems. 
Table 1. Technological schemes of recultivation of oil=contaminated peat bog soils after completion of oil spill elimination.

\begin{tabular}{|c|c|c|c|c|c|}
\hline \multirow[t]{4}{*}{ Categories } & \multirow{4}{*}{$\begin{array}{l}\text { Location } \\
\text { and other } \\
\text { features of } \\
\text { the site }\end{array}$} & \multicolumn{4}{|c|}{ Description of the oil-contaminated site } \\
\hline & & \multicolumn{2}{|c|}{$\begin{array}{l}\text { Spill of previous years } \\
\text { (bituminous oil fractions) }\end{array}$} & \multicolumn{2}{|c|}{$\begin{array}{l}\text { Current spill (after } \\
\text { completion of elimination) }\end{array}$} \\
\hline & & \multicolumn{4}{|c|}{ Major technological operations } \\
\hline & & Method 1 & Method 2 & Method I & Method 2 \\
\hline $\begin{array}{l}\text { 1. Land of } \\
\text { forest, water } \\
\text { resources, } \\
\text { municipal } \\
\text { with special } \\
\text { terms of use }\end{array}$ & $\begin{array}{c}\text { Cities' green } \\
\text { belts } \\
\text { Specially } \\
\text { protected } \\
\text { territories } \\
\text { Water } \\
\text { protection } \\
\text { zones } \\
\text { Sites near } \\
\text { federal } \\
\text { roadways }\end{array}$ & $\begin{array}{c}\text { Mechanized } \\
\text { loosening } \\
\text { Application of } \\
\text { mineral } \\
\text { fertilizers and } \\
\text { lime (with pH } \\
\text { below 5) } \\
\text { Sowing of } \\
\text { perennial grass } \\
\text { when oil content } \\
\text { below } 12 \% \\
\text { doses of seeds } \\
20-25 \mathrm{~kg} / \mathrm{ha} \text {. }\end{array}$ & $\begin{array}{l}\text { Mechanized } \\
\text { loosening to } \\
\text { improve } \\
\text { aeration } \\
\text { Application of } \\
\text { mineral } \\
\text { fertilizers and } \\
\text { lime } \\
\text { Treatment with } \\
\text { biological } \\
\text { preparations }\end{array}$ & $\begin{array}{l}\text { Peat } \\
\text { application to } \\
\text { reduce oil } \\
\text { content to } \\
10-12 \% \text {, } \\
\text { milling } \\
\text { Application } \\
\text { of mineral } \\
\text { fertilizers, } \\
\text { lime } \\
\text { Seeding of } \\
\text { grass, sowing } \\
\text { of plants }\end{array}$ & $\begin{array}{l}\text { Treatment } \\
\text { with bacterial } \\
\text { preparation } \\
\text { Addition of } \\
\text { mineral } \\
\text { fertilizers, } \\
\text { liming }\end{array}$ \\
\hline $\begin{array}{l}\text { 2. Land of } \\
\text { forest } \\
\text { reserves }\end{array}$ & $\begin{array}{c}\text { Forest and } \\
\text { swampy sites } \\
\text { not under } \\
\text { Category } 1 \\
\text { Sites with } \\
\text { risk of oil } \\
\text { washout and } \\
\text { spreading } \\
\text { Closed } \\
\text { drainless pits }\end{array}$ & 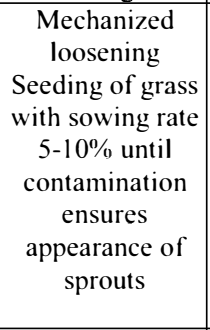 & $\begin{array}{l}\text { Mechanized } \\
\text { loosening } \\
\text { Treatment with } \\
\text { biological } \\
\text { preparations }\end{array}$ & $\begin{array}{l}\text { Treatment } \\
\text { with a } \\
\text { biological } \\
\text { preparation } \\
\text { Agricultural } \\
\text { engineering } \\
\text { techniques }\end{array}$ & $\begin{array}{l}\text { Leaving for } \\
\text { natural } \\
\text { purification } \\
\text { and ramping }\end{array}$ \\
\hline $\begin{array}{l}\text { 3. Land of } \\
\text { forest } \\
\text { reserves }\end{array}$ & $\begin{array}{c}\text { Sites after } \\
\text { burning out } \\
\text { of spilled oil, } \\
\text { acc. to oil } \\
\text { spill response } \\
\text { plan }\end{array}$ & $\begin{array}{c}\text { Mechanized } \\
\text { loosening } \\
\text { Seeding of grass } \\
\text { with sowing rate } \\
5-10 \%\end{array}$ & $\begin{array}{l}\text { Mechanized } \\
\text { loosening }\end{array}$ & $\begin{array}{l}\text { Mechanized } \\
\text { loosening }\end{array}$ & $\begin{array}{l}\text { Leaving for } \\
\text { natural } \\
\text { purification } \\
\text { and ramping }\end{array}$ \\
\hline
\end{tabular}

\section{CONCLUSIONS}

- The ultimate goal of recultivation activities is to bring oil-contaminated sites back to approved standards, and to optimize water, air, and food conditions of soils for vegetation of cultivated or wild flora.

- Recultivation flow charts vary depending on soil types, volume of the spilled oil, location of the oil-contaminated site, the spillage period, etc.

- The most rigid requirements to the cleaning of territories and to the quality of recultivation activities should be on areas within cities' and settlements' green belts, in water protection zones, on conservation areas, along federal roadw 